\title{
Online Book Shopping in Indonesian During the COVID-19 Pandemic
}

\author{
Lissa Rosdiana Noer ${ }^{1}$ Syaifurrizal Wijaya Putra ${ }^{1} \cdot$ Annisa Adinda Adriani ${ }^{1}$ \\ Published online: 26 January 2022 \\ (c) The Author(s), under exclusive licence to Springer Science+Business Media, LLC, part of Springer Nature \\ 2022
}

\begin{abstract}
The COVID-19 pandemic has lead to the implementation of quarantine for the entire world community. This is done to prevent the spread of COVID-19 and death from it. This impact is also felt by students who have to do many activities including buying books online. In Indonesia, Tokopedia and Shopee are the best-selling e-commerce platforms used by the public to buy books online. Moreover, each of these e-commerce has a fairly practical payment system, namely OVO and ShopeePay. This study tries to test the real motives of Indonesian consumers in buying books online. The method chosen was through structural equation modeling (SEM) which was carried out on two samples. The results show that Tokopedia consumers with OVO payments have hedonic motivation and utilitarian motivation in buying books online. In addition, the data also shows that Shopee consumers who pay through ShopeePay have other reasons besides hedonic and utilitarian motivation. The reason is because of situational influence.
\end{abstract}

Keywords Online book shopping $\cdot$ e-Commerce $\cdot$ e-Wallet $\cdot$ Structural equation modeling

\section{Introduction}

The COVID-19 pandemic is still not over around the world. Many countries are still struggling to overcome the economic, health, and social impact of this pandemic [1]. Many epidemiologists argue that the effects of a pandemic will end once heard immunity has been achieved. Herd immunity is a condition where the majority of a country's population can recover from the disease caused by the spread of COVID19. Vaccination is considered to be one of the solutions to achieve herd immunity.

Lissa Rosdiana Noer

lissa_rn@mmt.its.ac.id; lissarosdiananoer@gmail.com

1 Sepuluh Nopember Institute of Technology, Surabaya, East Java, Indonesia 
Many countries are racing to produce vaccines and speed up the vaccination process [2].

The trend of COVID-19 infection in Indonesia itself is also still quite high until August 2021. Mainly because of the delta variant that creates a second wave of infections in Indonesia. The pandemic situation has forced the government to prohibit people from doing activities outside their home [3]. The Indonesian government calls it the Enforcement of Restrictions on Community Activities. The rules are made to prevent more infections in the community [4]. People are forced to adapt by doing more activities at home. Most people are getting used to doing activities at home. It also encourages people to buy all the necessities of life online [5].

Restrictions on community activities also have an impact on the world of education. All students at the elementary to high school level must do online learning [6]. The implementation of school administration must also be done online. At first this was difficult to do because of limited technological capabilities. The limitations of this technological capability occur due to economic factors, knowledge and experience factors as well as infrastructure factors [7]. The economic factor in question is the difficulty of doing online school when many students cannot afford electronic devices and Internet packages [8]. The knowledge and experience factors in question are the lack of experience and knowledge of teachers and students in using hardware or software technology properly. The infrastructure factor in question is the number of regions in Indonesia that are not able to have good Internet access (signal and electricity). This is usually the case for the frontier, outermost and least developed regions of Indonesia.

However, as time passed, the Indonesian government tried to help the students through assistance with the problem. The assistance is in the form of providing smartphones and Internet quotas to students in need [9]. Infrastructure assistance is also carried out through the construction of Internet and electricity signal towers in each frontier, outermost, and least developed region. The government also provides training to every teacher and student through online teaching guidelines that have been published by the Ministry of Education, Culture, Research and Technology so that teachers and students can adapt to online-based education.

If you look closely, there is other problems that arises, namely, the distribution of online-based textbooks that will be used in learning [10]. However, there is a difference in the distribution of book needs between elementary, middle and high school levels. Elementary and secondary school students will be provided with textbooks by the school administrator [11]. Meanwhile, college students must find and buy the books needed for each subject that will be taught. While some college libraries can provide the required textbooks, sometimes the number of copies of the textbooks cannot meet the number of student needs. So, students who do not get the textbooks, have to buy it at a bookstore.

Based on research conducted by Nguyen et al. [12], it can be concluded that online sales of student textbooks have increased during the pandemic compared to before the pandemic. The majority of students buy books online because of the sense of need for books (utilitarian) and the influence of the pandemic situation where there is a government ban on leaving the house. 
In Indonesia itself, there are several bookstores owned by publishing companies such as PT Gramedia Pustaka Utama, PT Elex Media Komputindo, PT Mizan Media Utama, PT Intan Pariwara, and CV Solusi Book Distribution. The companies said there was a decline in book sales at their physical stores. The decline in book sales was due to the impact of the COVID-19 pandemic. According to research conducted by Hapsari (2020), it was found that there was a decline in book sales due to the impact of the COVID-19 pandemic. The research found that $58.2 \%$ of book publishers experienced a decrease in sales exceeding $50 \%$ than usual, $29.6 \%$ of publishers experienced a decline in sales between 31 and $50 \%, 8.2 \%$ of publishers experienced a decline between 10 and $30 \%$ and as many as $4.1 \%$ publishers reported relatively low sales, the same as normal days [13].

There are several online marketplaces that provide textbook sales for students. However, based on a survey report from Nurhayati-Wolff [14], it can be concluded that there are two marketplaces that have the largest number of users in Indonesia, namely Shopee and Tokopedia. Tokopedia is ranked first in a survey regarding the number of marketplace users in Indonesia with 135 million active users. Furthermore, Shopee followed in second place with 127 million active users. These two marketplaces each have quite a variety of payment methods. However, both have flagship e-wallets that often offer price discounts. Shopee has an e-wallet called ShopeePay, while Tokopedia has OVO. If we look deeper, e-wallet is a technology that can help people transact more easily, and is safe from cyber threats and it offers many discounts (financial benefits for users). In a pandemic condition, e-wallet can also help the community to avoid COVID-19 infection because people can reduce shopping transactions by touching physical money.

This research is expected to develop the findings of the research conducted by Nguyen et al. [12] in Vietnam. The development carried out in this research is through testing in Indonesia. So, it can be seen whether there is a difference between online book shopping in Indonesia and Vietnam. In addition, this study also wants to know the difference between the online book shopping phenomenon in using ShopeePay and OVO.

\section{Literature Review}

\section{Students and Book Needs}

Internet technology has made it easier for students to use e-commerce to find study needs in the form of textbooks. The price of textbooks displayed on the Internet is cheaper when it is compared to the price in traditional stores. The lower prices offered on the Internet are favored by students, but that is not the only issue to consider [15]. Research conducted by Sun et al. [16] found that there is a relationship between a person's attitude and intention to use technology based on usability and ease of use. In addition to textbooks sold in e-commerce, students can also access electronic textbooks or e-textbooks via the Internet.

Research conducted by Nicholas and Lewis [17] on millennial attitudes towards books and e-books, found that "although millennial students are quite familiar with 
the use of various forms of technology in their daily lives, millennial students prefer to read books that have ancient prints". Millennial consumers are a generation born from 1980 to 2000, and have characteristics including: preferring reading through smartphones to conventional reading, having social media accounts as a means of communication and seeking information, choosing smartphones over television, and making family their center of consideration and decision making [18]. The findings are also the same as the finding of research conducted by Shelburne [19] regarding awareness of the use or disadvantage of e-books and opinions about e-books. The results show that users perceive e-books to be better than printed books in terms of space and storage, 24/7 accessibility, up-to-date information, and availability of location access.

Students who read e-textbooks need additional skills to be able to learn, understand, and interact with technology. Students also try to understand the basic functionality of e-textbooks (to find reading materials, bookmark, use highlighting tools and write notes) [20]. In addition, previous research has shown that emotional attachment is an obstacle in adapting to using e-textbooks [21]. Results of research conducted Shepperd et al. [22] related to the perception and performance of students who use electronic textbooks versus traditional paper textbooks found that students who use electronic textbooks reported that they spent less time reading, compared to students who use traditional paper textbooks and generally evaluated electronic textbooks poorly. To meet the need for digital collections, digital collection providers must be able to preserve the age of data storage media. Factors that must be considered by digital collection providers include: organizational infrastructure, technology infrastructure, and available resources [23].

\section{Situational Influence}

The COVID-19 pandemic has led to lockdowns in many countries. The lockdown has significantly disrupted business. Individual fear of contracting the COVID-19 virus has resulted in changes in shopping habits. Today's consumers prefer shopping from home to store shopping because consumers perceive shopping from home to be less risky [24]. The COVID-19 pandemic is one of the effective situational factors in changing consumer intentions into online ordering behavior [25]. Consumers' choice of online channels is largely determined by situational effects [26, 27]. Consumers have three main motives for online shopping, including [28]: (1) many stores have switched to providing products from offline to online, (2) reducing health risks, and (3) saving time.

The selection of online channels leads to intense market competition in the growth of e-commerce. Businesses must be able to understand different customer preferences and behaviors and group them together to develop specific strategies to better serve consumers [29]. Improved online services in e-commerce are needed to attract consumers and gain trust [30]. The use of e-commerce is an option that individuals can use to meet consumer needs [31]. The use of e-commerce makes it easier for consumers to make contactless payments and provides greater security/protection [5]. Research conducted by Milaković [32] showed that consumer adaptation 
to online shopping moderates the relationship between consumer resilience and purchase satisfaction. In addition, other research has shown a change in the pattern of traditional shopping behavior into online shopping behavior among consumers in the Czech Republic (Baby Boomers, generations X and Y), which dominated at the beginning of the second wave of the COVID-19 pandemic [4].

In addition to shifting consumer shopping behavior from offline to online, The COVID-19 pandemic has changed face-to-face offline learning into online learning (e-learning) in various countries [6].

\section{Utilitarian Motivation}

Utilitarian shopping motivation reflects the consumer's desire to make efficient, rational and task-oriented efforts [33]. Consumers tend to use technology services, such as mobile applications, to simplify a process, in terms of performance expectations, information availability, and time convenience [34]. The role of information availability as a utilitarian motivation for online shopping is important [35]. The availability of such information comes from the quantity of information that can be obtained, compared to the limited amount of information that vendors provide in physical form [36]. Utilitarian motivation is related to functional, economic, rational, practical, or extrinsic benefits [37].

There is a six-dimensional structure of consumer utilitarian motivation, most of which focuses on online shopping including cost savings, convenience, selection, information availability, lack of socialization (lack of sociability), and a customized product or service $[35,38]$. Consumers who have utilitarian motivation, already have information such as information about price, product features or specifications and other aspects related to the product before deciding to buy [39].

Research that has been conducted explored the utilitarian shopping motivation in online shopping and validated these factors through confirmatory factor analysis (CFA) in the context of India [40]. The results showed that there were five motivational factors for utilitarian online shopping, including: information availability, accessibility, searchability, product availability and convenience. Another study examined the utilitarian motivations that may influence UK wholesale consumers to adopt and use proposed new features for in-store applications [34]. The results support that utilitarian motivations for grocery shopping include time convenience, performance expectancy and information availability.

\section{Hedonic Motivation}

Shopping motivation is a behavior that brings consumers to the market to fulfill internal needs [41]. In addition to shopping for necessities, consumers also have hedonic motivation for shopping [42]. Hedonic consumption is a behavioral aspect related to multisensory, fantasy, and emotive aspects of consumption [43]. A typical hedonic consumer has shopping motivations, namely, adventure (adventure shopping), gratification (gratification shopping), role (role shopping), value (value 
shopping), social (social shopping), and idea (idea shopping) [44]. Hedonic tendencies of consumer in shopping can lead to compulsive buying (excessive buying with weak control) [42].

Consumers have various opportunities related to how to find, compare, buy, and obtain goods and services. Consumer experience is the main determinant of consumer behavior in determining omnichannel [45]. Consumers of offline stores and online stores who have hedonic motivations value fun, entertainment, and exploration [35]. Consumers who have hedonic shopping motivation, have a more important role in the context of online buying [46]. The hedonic features of the online channel, have given rise to shopping which contributes to the development of obsessive-compulsive buying [47]. Consumers with compulsive tendencies have a constant preoccupation with shopping and use shopping as a means to reduce anxiety [48]. Research that has been carried out examines the relationship between hedonic shopping motivation and compulsive online purchases. The results show that different hedonic motivations contribute to compulsive online purchases. The search for satisfaction and shopping ideas is the main motivation for compulsive online shoppers (some women are shopping satisfaction seekers, while men are mostly shopping information seekers) [49].

Every social media platform has strengths and weaknesses. Marketers must be able to understand the characteristics of each social media platform in order to develop an effective media placement strategy. Interactive brand posts are responded to more often than informative message content [50]. Brand content that emphasizes hedonic entertainment messages is more persuasive on social media Instagram [51].

Another study also examined the relationship between hedonic motivation and behavioral intentions to use electronic money with payment habits as a mediator. The results of the study indicate that consumer's tendency of hedonic motivation has an influence on payment habits [52].

\section{Online Purchase Intention}

A consumer can make purchases online or from offline stores, request home delivery or self-collection, and return/exchange purchases at pick-up points or physical stores [53]. The COVID-19 pandemic has changed purchasing behavior from offline to online to reduce cases of transmission of the virus. The attitude that a consumer has in online purchases is influenced by the trust and benefits provided [54]. In addition, innovations in technology also affect consumer attitudes towards online purchases [55].

When people shop for books online, the first step is usually to check availability, followed by finding the best prices [56]. Technological developments provide convenience in the process of purchasing all types of books online. Buying books online is considered more time-saving than buying books offline or through stores [57]. However, online purchases also have problems. These constraints are consumer complaints caused by defective products, products received that do not meet expectations, or discontinued products in their order. Consumer complaints can be minimized by providing online preview facilities, making it easier for consumers 
to review products. Online reviews have a positive effect on consumers' purchase intentions for products [58]. Online reviews provided by consumers can be positive word of mouth and negative word of mouth. Research conducted by Mardhiyah et al. [59] shows that the factors that influence consumers' intention to engage in negative WOM in online communication are complaint success, altruism, retaliatory intent, and complaint costs. Consumers choose to see negative WOM communications online because these comments perceive that complaints submitted directly to service providers do not get a response as expected.

Another obstacle faced by consumers is the fluctuating prices on the Internet due to the supply of sellers and shifts in demand from buyers. The most common form of consumer payment for purchases over the Internet is credit card payments. Despite consumer concerns about payment security, most credit card companies have fraud protection in place (either online or off) [60]. The effects of buying books online were also investigated. The results showed that students who bought their textbooks online rather than in bookstores were more skilled with computers and Internet use when compared to students who bought their textbooks at university bookstores [61].

\section{Hypotheses}

To make a clearer noted of this research, assumptions must be made so that they can be proven through field research. Based on the previous explanation, several hypotheses can be proposed. These hypotheses will explain the difference between Shopee with its ShopeePay payment system and Tokopedia with a payment system called OVO. These differences will be associated with the variables described previously. Thus, the description of the hypotheses is as follows:

H1a Situational influence has a positive effect on online purchase intention in the Shopee-ShopeePay case.

H1b Utilitarian motivation has a positive effect on online purchase intention in the Shopee-ShopeePay case.

H1c Hedonic motivation has a positive effect on online purchase intention in the Shopee-ShopeePay case.

$\mathrm{H} 2 \mathrm{a}$ Situational influence has a positive effect on online purchase intention in the Tokopedia-OVO case.

H2b Utilitarian motivation has a positive effect on online purchase intention in the Tokopedia-OVO case.

$\mathrm{H} 2 \mathrm{c}$ Hedonic motivation has a positive effect on online purchase intention in the Tokopedia-OVO case. 
H3a The influence of situational influence on online purchase intention in the Shopee-ShopeePay case is greater than in the Tokopedia-OVO case.

H3b The effect of utilitarian motivation on online purchase intention in the ShopeeShopeePay case is greater than in the Tokopedia-OVO case.

H3c The effect of hedonic motivation on online purchase intention in the ShopeeShopeePay case is greater than in the Tokopedia-OVO case.

\section{Research Method}

\section{Measures}

In order to test each variable, research measures will be taken based on several previous studies, for example Jahn and Kunz [62], Nguyen et al. [12], and San Martín and Herrero [63]. All items in this study also used Likert with five-point

Table 1 Variables and indicator items

\begin{tabular}{ll}
\hline Item code & Variable \\
\hline SIT1 & Situational influences \\
MIT2 & $\begin{array}{l}\text { There are significant health risks associated with visiting physical bookstores } \\
\text { during the COVID-19 pandemic }\end{array}$ \\
SIT3 & Online bookstores extend their product portfolio during the COVID-19 pandemic \\
SIT4 & Online bookstores offer more sales promotions during the COVID-19 pandemic \\
SIT5 & Online shopping is a trend during the COVID-19 pandemic \\
UTI1 & Utilitarian motivation \\
UTI2 & Online book shopping is helpful \\
UTI3 & Online book shopping is useful \\
UTI4 & Online book shopping is functional \\
& Online book shopping is practical \\
HED1 & Hedonic motivation \\
HED2 & Online book shopping is fun \\
HED3 & Online book shopping is exciting \\
HED4 & Online book shopping is pleasant \\
OPI1 & Online book shopping is entertaining \\
OPI2 & Online purchase intention \\
& I will probably buy books on Tokopedia and use OVO in the near future \\
I shortly to buy books on Tokopedia and use OVO
\end{tabular}

Source Nguyen et al. [12] 
Likert scale that ranged from "strongly agree" (5) and "strongly disagree" (1). Each research variable used in this study will continue the research from Nguyen et al. [12] (Table 1).

\section{Data Collection and Sample}

The target of this research is students who are still studying online and spread throughout Indonesia. Thus, the research sample was taken from students who voluntarily filled out the questionnaire. The number of samples from this study was 540 undergraduate students from various study programs. Two Hundred and fifty students filled out questionnaires regarding purchasing books through Tokopedia website and paying for them via OVO. Furthermore, 290 other students filled out questionnaires regarding purchasing books through Shopee website and paying for them through ShopeePay.

\section{Structural Equation Modelling (SEM)}

The variables used in this study were in the form of constructs that have more than one indicator. Thus, the most appropriate data analysis tool is structural equation modeling (SEM). The test was carried out twice for each sample from Tokopedia-OVO and Shopee-ShopeePay. Thus, it can be seen the difference between the two e-commerce platforms and their e-wallets.

\section{Data Analysis}

Based on the first study conducted on Tokopedia consumers who used OVO as payment methods, several findings were found. The first finding showed that the coefficient value of the situational influences variable on online purchase intentions was 0.08 . However, the probability value of the relationship actually showed the number 0.123 , which exceeded the specified alpha of $5 \%$. So it can be concluded that Hypothesis 1a is rejected. Online purchase intentions are not influenced by situational influences in the Tokopedia-OVO case.

Table 2 Comparison Between Tokopedia-OVO and Shopee-ShopeePay in terms of Online Book Shopping

\begin{tabular}{lllllll}
\hline Comparison & Item relationship & & & Estimate & $P$ \\
\hline Tokopedia-OVO & Online_Purchase_Intentions & $\leftarrow$ & Situational_Influences & 0.079 & 0.123 \\
& Online_Purchase_Intentions & $\leftarrow$ & Utilitarian_Motivation & 0.261 & 0.004 \\
& Online_Purchase_Intentions & $\leftarrow$ & Hedonic_Motivation & 0.528 & 0.001 \\
Shopee-ShopeePay & Online_Purchase_Intentions & $\leftarrow$ & Situational_Influences & 2.038 & 0.015 \\
& Online_Purchase_Intentions & $\leftarrow$ & Utilitarian_Motivation & 0.322 & 0.015 \\
& Online_Purchase_Intentions & $\leftarrow$ & Hedonic_Motivation & 0.721 & 0.000 \\
\hline
\end{tabular}


The next finding was that utilitarian motivation had an influence coefficient of 0.26 on online purchase intentions. In addition, the effect of hedonic motivation on online purchase intention also had the largest coefficient, which was of 0.53 . These two relationships each had a significance value of 0.004 and 0.001 which are below $5 \%$. So it can be concluded that Hypotheses $1 \mathrm{~b}$ and 1c are accepted (see Table 2).

The second study, on Shopee consumers who use ShopeePay payments obtained several findings. The first finding showed that the coefficient value of the situational influences variable on online purchase intentions was 2.038 with a significance value of 0.015 . The next finding was that utilitarian motivation had an influence coefficient of 0.322 on online purchase intentions with a significance value of 0.015 . In addition, the effect of hedonic motivation on online purchase intention had a coefficient of 0.721 with a significance value of 0.015 . So it can be concluded that the three variables are proven to be able to positively influence online purchase intention (see Table 2) and that the $\mathrm{H} 2 \mathrm{a}, \mathrm{H} 2 \mathrm{~b}$ and $\mathrm{H} 2 \mathrm{c}$ hypotheses are accepted (Fig. 1).

Furthermore, based on the coefficient value presented in Table 2, it can be concluded that situational influences only affect online purchase intentions in the case of Shopee-ShopeePay, but not in the case of the Tokopedia-OVO. So, it can be concluded that the Hypothesis $\mathrm{H} 3 \mathrm{a}$ is rejected. In addition, utilitarian motivation and hedonic motivation affect Shopee-ShopeePay more than they affect Tokopedia-OVO. So it can be concluded that $\mathrm{H} 3 \mathrm{~b}$ and $\mathrm{H} 3 \mathrm{c}$ are accepted (Fig. 2).

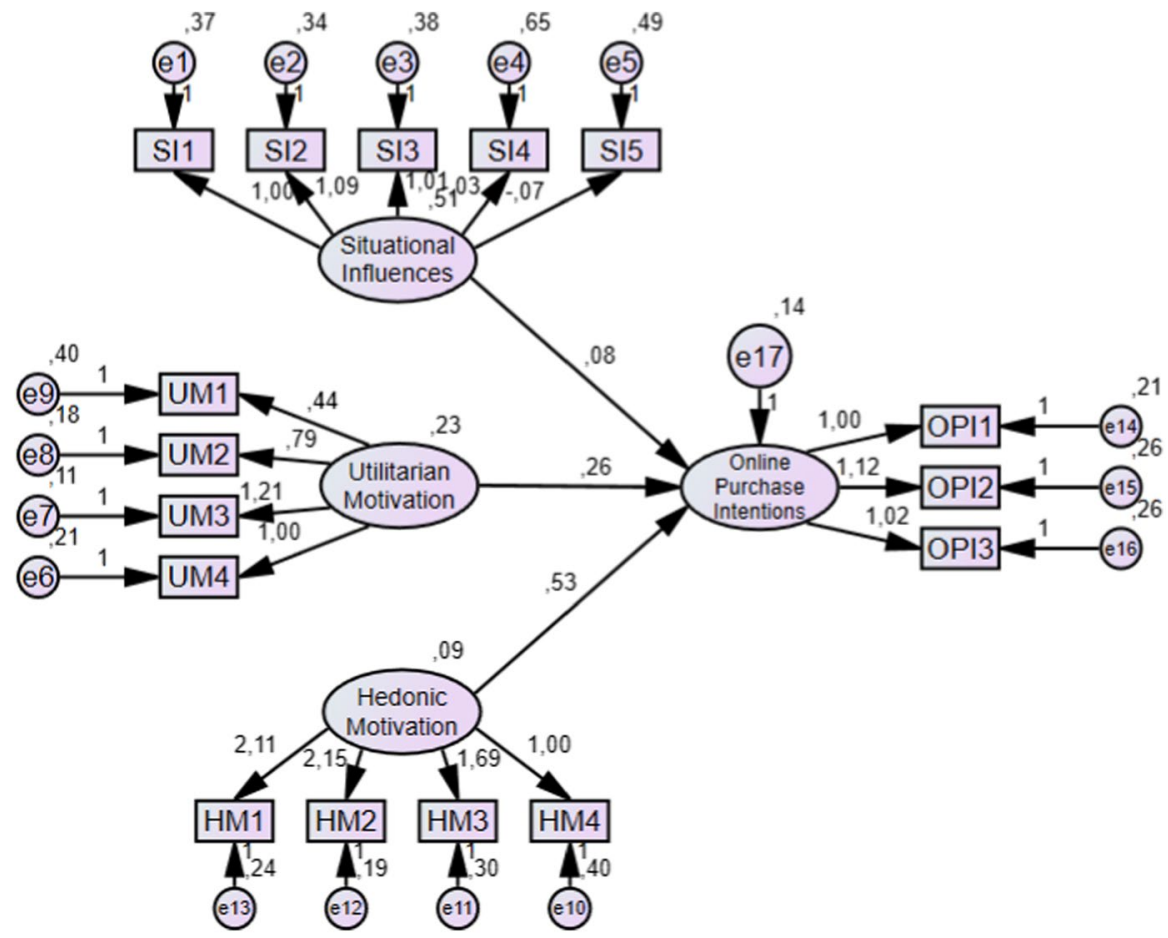

Fig. 1 Analysis of online book shopping on Tokopedia 


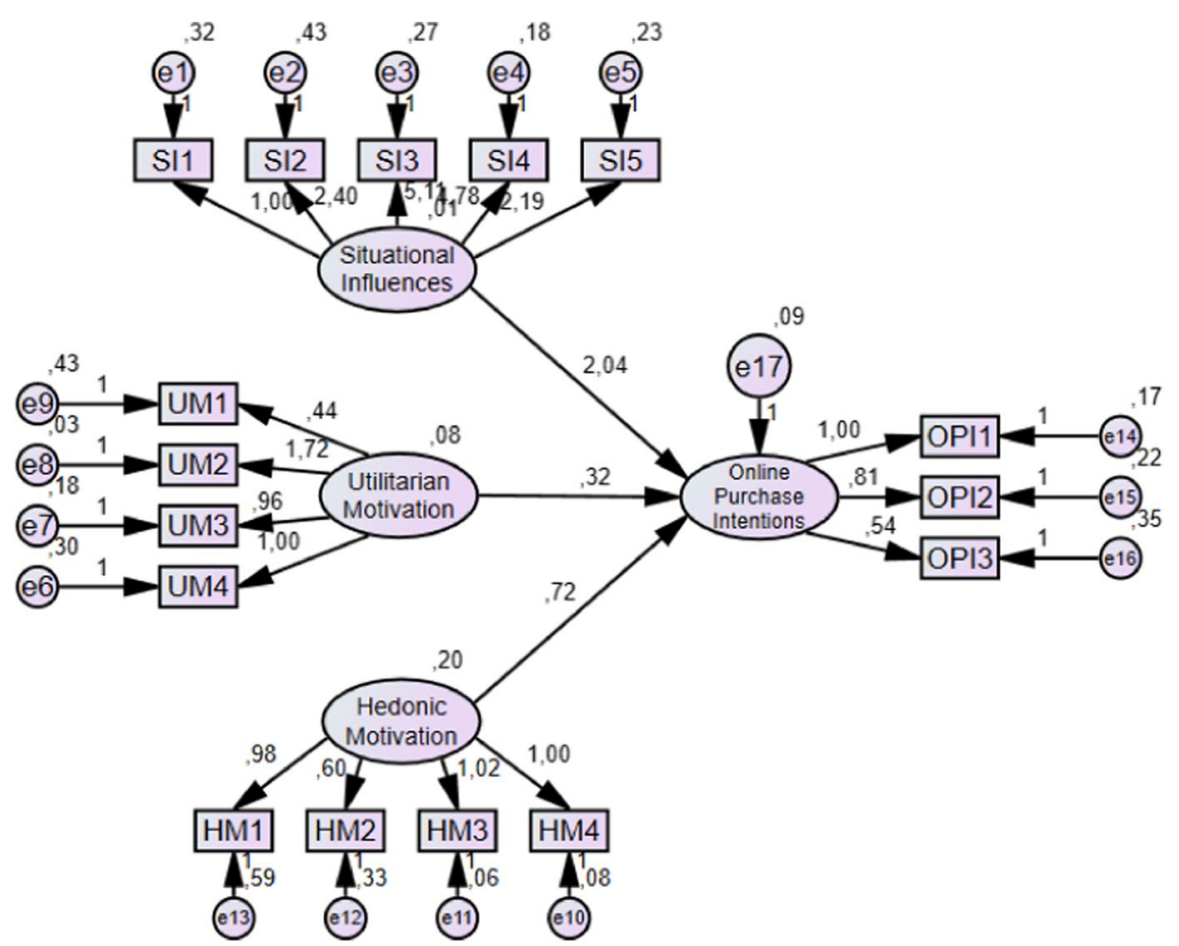

Fig. 2 Analysis of online book shopping on Shopee

\section{Discussion}

The situational influence in the form of a pandemic has forced the world community to buy necessities online to avoid the spread of COVID-19. This condition also occurs in students who need to purchase books and the purchase is required to be made online. However, not all e-commerce platforms have consumers who buy because of situational influence motives, for example, Tokopedia with payments via OVO where consumers are not affected by the COVID-19 pandemic. Tokopedia-OVO consumers tend to buy because of utilitarian and hedonic motives.

On the other hand, Shopee with ShopeePay payment methods has a different story about buying books online. Student consumer motive for buying books is because of situational influence, utilitarian motivation and hedonic motivation. However, it is situational influence that has the biggest influence on the motive for buying books online. This means that Indonesian people tend to know Shopee and transaction payments using ShopeePay in online shopping during a pandemic. Shopee may still have less users than Tokopedia, but Shopee wins brand equity in hedonic and consumer utilitarian motives.

More time is spent reading books during the pandemic than before the pandemic. This happens because the whole community is required to carry out activities online. In addition, the impact that student feel the most is that they have to buy books online because they have to follow quarantine rules from the government. 
This study proves that Shopee with its ShopeePay has more brand equity for students than Tokopedia with OVO.

\section{Conclusion}

This study proves that Shopee-ShopeePay is more able to influence student consumers to buy online compared to Tokopedia-OVO. Shopee-ShopeePay consumers tend to buy books because of situational influence, hedonic motivation and utilitarian motivation. Meanwhile, Tokopedia-OVO consumers tend to buy books because of hedonic motivation and utilitarian motivation. Even though Shopee has fewer users than Tokopedia, Shopee is able to form more brand equity for student consumers.

\section{References}

1. Gibson J, Olivia S. Direct and indirect effects of COVID-19 on life expectancy and poverty in Indonesia. Bull Indones Econ Stud. 2020;56(3):325-44.

2. Ratzan SC, Sommariva S, Rauh L. Enhancing global health communication during a crisis: lessons from the COVID-19 pandemic. Public Health Res Pract. 2020;30(2):1-6.

3. Roggeveen AL, Sethuraman R. How the COVID-19 pandemic may change the world of retailing. J Retail. 2020;96(2):169-71.

4. Eger L, Komárková L, Egerová D, Mič́́k M. The effect of COVID-19 on consumer shopping behaviour: generational cohort perspective. J Retail Consum Serv. 2021;61:102542.

5. Mehrolia S, Alagarsamy S, Solaikutty VM. Customers response to online food delivery services during COVID-19 outbreak using binary logistic regression. Int J Consum Stud. 2020;45(3):1-13.

6. Favale T, Soro F, Trevisan M, Drago I, Mellia M. Campus traffic and e-Learning during COVID-19 pandemic. Comput Netw. 2020;176:107290.

7. Hao Y, Jackson K. Student satisfaction toward e-textbooks in higher education. J Sci Technol Policy Manag. 2014;5(3):231-46.

8. Pietrzak M. Use of information and communication technology and resources of the Internet in education natural sciences. In: Current topics in Czech and Central European geography education, Institute of Geography and Spatial Management, Jagiellonian University in Kraków, ul. Gronostajowa, Kraków, 730-387, Warsaw: Springer; 2016. pp. 147-68.

9. Budiman E, Hairah U. Decision making analysis for free Internet quota assistance online learning during the COVID-19 pandemic. IOP Conf Ser Mater Sci Eng. 2021;1071(1):012023.

10. de Oliveira SM. E-textbooks usage by students at Andrews University: a study of attitudes, perceptions, and behaviors. Libr Manag. 2012;33(8):536-60.

11. Vaughn S, Bos CS. Strategies for teaching students with learning and behavior problems. Upper Saddle River: Pearson; 2012.

12. Nguyen HV, Tran HX, Van Huy L, Nguyen XN, Do MT, Nguyen N. Online book shopping in Vietnam: the impact of the COVID-19 pandemic situation. Publ Res Q. 2020;36(3):1-9.

13. Hapsari AY, Bonita BB, Kurnia SN, Ilham R, Ramadina T, Widyatama U. Gramedia Bookstore Bandung strategy to face online sales competition on the marketplace. Turk J Physiother Rehabil. 2020;32:3.

14. Nurhayati-Wolff H. Top 10 e-commerce sites in Indonesia as of 1 st quarter 2021, monthly traffic. 2021. https://www.statista.com/statistics/869700/indonesia-top-10-e-commerce-sites/. Accessed 05 Nov 2021.

15. Talaga JA, Tucci LA. Consumer tradeoffs in on-line textbook purchasing. J Consum Mark. 2001;18(1):10-20.

16. Sun PC, Tsai RJ, Finger G, Chen YY, Yeh D. What drives a successful e-Learning? An empirical investigation of the critical factors influencing learner satisfaction. Comput Educ. 2008;50(4):1183-202. 
17. Nicholas AJ, Lewis JK. Millennial attitudes toward books and e-books. Int J Book. 2008;5(2):81-92.

18. Handriana $\mathrm{T}$, et al. Purchase behavior of millennial female generation on Halal cosmetic products. $\mathbf{J}$ Islam Mark. 2020. https://doi.org/10.1108/JIMA-11-2019-0235.

19. Shelburne WA. E-book usage in an academic library: user attitudes and behaviors. Libr Collect Acquis Tech Serv. 2009;33:59-72.

20. Stites-Doe S, Maxwell PE, Kegler JL. Business students' learning engagement as a function of reading assigned e-textbooks. Cut Edge Technol High Educ. 2013;6(Part D):239-70.

21. Srirahayu DP, Nurpratama MR, Handriana T, Hartini S. Effect of gender, social influence, and emotional factors in usage of e-Books by Generation $\mathrm{Z}$ in Indonesia. Digit Libr Perspect. 2021;37(4):325-7.

22. Shepperd JA, Grace JL, Koch EJ. Evaluating the electronic textbook: is it time to dispense with the paper text? Teach Psychol. 2008;35:2-5.

23. Srirahayu D, Harisanty D, Su'adaa M. Readiness for digital preservation in Indonesia. Libr Philos Pract. 2020:2-14.

24. Park J, Lennon SJ, Stoel L. On-line product presentation: effects on mood, perceived risk, and purchase intention. Psychol Mark. 2005;22(9):695-719.

25. Ali S, Khalid N, Javed HMU, Islam DMZ. Consumer adoption of online food delivery ordering (OFDO) services in Pakistan: the impact of the COVID-19 pandemic situation. J Open Innov Technol Mark Complex. 2021;7:1-23.

26. Kazancoglu I, Demir B. Analysing flow experience on repurchase intention in e-retailing during COVID-19. Int J Retail Distrib Manag. 2021. https://doi.org/10.1108/IJRDM-10-2020-0429.

27. Chocarro R, Cortiñas M, Villanueva ML. Situational variables in online versus offline channel choice. Electron Commer Res Appl. 2013;12(5):347-61.

28. Bytyçi S, Shala V, Ziberi B, Myftaraj E. Transforming traditional business into online: the impact of COVID-19 pandemic on consumer behavior. J Gov Regul. 2021;10(2 Special Issue):300-8.

29. Akar E. Customers' online purchase intentions and customer segmentation during the period of COVID-19 pandemic. J Internet Commer. 2021;20(3):371-401.

30. Raza SA, Khan KA. Corona fear and e-commerce adoption in an emerging economy: paradigm shift of consumer intention. Foresight. 2021. https://doi.org/10.1108/FS-02-2021-0034.

31. Cui Y, Mou J, Cohen J, Liu Y. Understanding information system success model and valence framework in sellers' acceptance of cross-border e-commerce: a sequential multi-method approach. Electron Commer Res. 2019;19(4):885-914.

32. Milaković IK. Purchase experience during the COVID-19 pandemic and social cognitive theory: the relevance of consumer vulnerability, resilience, and adaptability for purchase satisfaction and repurchase. Int J Consum Stud. 2021;45(6):1425-42.

33. Anderson ET, Simester DI. Reviews without a purchase: low ratings, loyal customers, and deception. J Mark Res. 2014;51:249-69.

34. Wang JPC, Gutierrez A. An in-store mobile app for customer engagement: discovering hedonic and utilitarian motivations in UK grocery retail. In: Lecture notes in business information processing. 2019, pp. 225-43.

35. To PL, Liao C, Lin TH. Shopping motivations on Internet: a study based on utilitarian and hedonic value. Technovation. 2007;27:774-87.

36. Wolfinbarger M, Gilly MC. Shopping online for freedom, control, and fun. Calif Manag Rev. 2001;43(2):34-55.

37. Martínez-López FJ, Luna-Huertas P, José Martínez F. Motivations for consumption behaviours on the web: a conceptual model based on a holistic approach. Int J Electron Mark Retail. 2006;1(1):3-20.

38. Martínez-López FJ, Pla-García C, Gázquez-Abad JC, Rodríguez-Ardura I. Utilitarian motivations in online consumption: dimensional structure and scales. Electron Commer Res Appl. 2014;13(3):1-17.

39. Chakraborty S, Soodan V. Examining utilitarian and hedonic motivations in online shopping in India: moderating effect of product browsing behavior. Int $\mathrm{J}$ Recent Technol Eng. 2019;8(1C2):117-25.

40. Kumar A, Kashyap AK. Leveraging utilitarian perspective of online shopping to motivate online shoppers. Int J Retail Distrib Manag. 2018;46(3):247-63.

41. Jin B, Kim J-O. A typology of Korean discount shoppers: shopping motives, store attributes, and outcomes. Int J Serv Ind Manag. 2003;14(4):396-419. 
42. Horváth $\mathrm{C}$, Adigüzel F. Shopping enjoyment to the extreme: hedonic shopping motivations and compulsive buying in developed and emerging markets. J Bus Res. 2018;86(July 2017):300-10.

43. Hirschman EC, Holbrook MB. Hedonic consumption: emerging concepts, methods and propositions. J Mark. 1982;46(3):92-101.

44. Arnold MJ, Reynolds KE. Hedonic shopping motivations. J Retail. 2003;79(2):77-95.

45. Tyrväinen $\mathrm{O}$, Karjaluoto $\mathrm{H}$, Saarijärvi H. Personalization and hedonic motivation in creating customer experiences and loyalty in omnichannel retail. $J$ Retail Consum Serv. 2020;57(August):102233.

46. Scarpi D, Pizzi G, Visentin M. Shopping for fun or shopping to buy: is it different online and offline? J Retail Consum Serv. 2014;21(3):258-67.

47. Kwon KN, Jain D. Multichannel shopping through nontraditional retail formats: variety-seeking behavior with hedonic and utilitarian motivations. J Mark Channels. 2009;16(2):149-68.

48. Ali A, Li C, Hussain A. Hedonic shopping motivations and obsessive-compulsive buying on the Internet. Glob Bus Rev. 2020. https://doi.org/10.1177/0972150920937535.

49. Wang X, Ali F, Tauni MZ, Zhang Q, Ahsan T. Effects of hedonic shopping motivations and gender differences on compulsive online buyers. J Mark Theory Pract. 2021. https://doi.org/10.1080/10696 679.2021.1894949.

50. Kusumasondjaja S. The roles of message appeals and orientation on social media brand communication effectiveness: an evidence from Indonesia. Asia-Pac J Mark Logist. 2018;30(4):1135-58.

51. Casaló LV, Flavián C, Ibáñez-Sánchez S. Antecedents of consumer intention to follow and recommend an Instagram account. Online Inf Rev. 2017;41(7):1046-63.

52. Khatimah H, Susanto P, Abdullah NL. Hedonic motivation and social influence on behavioral intention of e-money: the role of payment habit as a mediator. Int J Entrep. 2019;23(1):1-9.

53. Wang X, Yuen KF, Wong YD, Teo CC. Consumer participation in last-mile logistics service: an investigation on cognitions and affects. Int J Phys Distrib Logist Manag. 2018;49(2):1-22.

54. Widyastuti W, Hartini S, Artanti Y. Revisiting the online shopper's behaviour in Indonesia: the role of trust and perceived benefit. Int J Ind Eng Manag. 2020;11(4):226-36.

55. Purwanto S, Hartini S, Premananto GC. The development and testing of technology acceptance models for consumers towards the intention to use e-wallet. In: 1st International conference on innovation in research, 2018, ICIIR 2018, vol 88, pp 55-61.

56. Lubiana L, Gammon JA. Bookselling-book buying: the European perspective of the online market. Libr Collect Acquis Tech Serv. 2004;28:373-96.

57. Atmojo RNP, Cahyani AD. Recommendations for development of online bookstore in Indonesia: a review from writer's perspective. J Comput Sci. 2014;10(8):1522-30.

58. Park DH, Lee J, Han I. The effect of on-line consumer reviews on consumer purchasing intention: the moderating role of involvement. Int J Electron Commer. 2007;11(4):125-48.

59. Mardhiyah D, Dharmmesta BS, Purwanto BM. Antecedents to intention to engage in the online negative word-of-mouth communication. Gadjah Mada Int J Bus. 2013;15(2):113-32.

60. Somsel L. Buying books online is no mystery. Collect Manag. 2004;29(3-4):41-52.

61. Yang B, Lester D. Buying books online: follow-up. Psychol Rep. 2003;92:393-4.

62. Jahn B, Kunz W. How to transform consumers into fans of your brand. SSRN Electron J. 2012;23(3):344-61.

63. San Martín H, Herrero Á. Influence of the user's psychological factors on the online purchase intention in rural tourism: integrating innovativeness to the UTAUT framework. Tour Manag. 2012;33:341-50.

Publisher's Note Springer Nature remains neutral with regard to jurisdictional claims in published maps and institutional affiliations. 